\title{
HUBUNGAN ANTARA BODY CONDITION SCORE (BCS) DENGAN PRODUKSI SUSU SAPI PERAH FRIESIAN HOLSTEIN (FH)
}

\section{CORRELATION BETWEEN BODY CONDITION SCORE (BCS) WITH MILK PRODUCTION OF FRIESIAN HOLSTEIN (FH) DAIRY CATTLE}

\author{
Melsa Netika ${ }^{1)}$, Roesno Darsono ${ }^{2)}$, *Budi Utomo ${ }^{3)}$, Imam $_{\text {Mustofa }}{ }^{4)}$, Ismudiono $^{5)}$, \\ Tri Wahyu Suprayogi') \\ ${ }^{1)}$ Student, ${ }^{2)}$ Departement of Veterinary Pathology, ${ }^{3,4,5,6}$ Department of Veterinary Reproduction \\ Faculty of Veterinary Medicine, Airlangga University \\ *Corresponding author: email:budi_reprovet@yahoo.com;netikamelsa@gmail.com
}

\begin{abstract}
The aim of this research was to observe the Body Condition Score (BCS) and milk production of Friesian Holstein (FH) dairy cattles. 144 of dairy cattles divided into 3 groups based on BCS 1-9 scale. The results showed that $\mathrm{Y}=6.62+5.54 \mathrm{X}-5.78 \mathrm{X}^{2}$. Coefficient of determination $\left(\mathrm{R}^{2}\right)$ of 20.6 this mean any increase in milk production by $20.6 \%$ is affected by BCS. It can be concluded that there is a correlation between Body Condition Score (BCS) and milk production. The higher BCS (BCS 7-8) the lower milk production, while in ideal BCS production (5-6) the production of milk is optimize.
\end{abstract}

Keywords: Body Condition Score, Milk Production.

\section{Latar Belakang}

Susu juga merupakan produk hewani yang sangat digemari semua kalangan. Kon-sumsi susu masyarakat Indonesia dari 6,8 liter per tahun, pada tahun 2005 meningkat men-jadi 7,7 liter per tahun pada tahun 2008 (se-tara dengan 25 gram per hari) (Dirjen Bina Produksi Peternakan, 2008).

Peningkatan konsumsi susu tidak diikuti dengan tersedianya pasokan susu dari dalam negeri. Industri susu di Indonesia hanya mampu memenuhi kebutuhan susu nasional sekitar 39,8\% dari permintaan yang ada, dan sisa kebutuhan susu 60,2\% masih dipenuhi oleh susu impor (Setyawan dkk., 2005). Produksi susu di Indonesia tahun 2013 mengalami penurunan sebesar $15 \%$. Penurunan produksi susu tersebut salah satunya disebabkan oleh produktivitas sapi perah yang rendah (Dirjen PPHP, 2014).

Produksi susu adalah bagian dari re-produksi karena mekanisme pembentukan susu seperti mammogenesis, laktogenesis dan galaktopoesis terjadi setelah sapi induk bereproduksi. Bobot badan juga berpengaruh terhadap reproduksi ternak seperti kesuburan, kebuntingan, proses kelahiran dan laktasi (Susilorini dkk., 2007). Apabila ternak mempunyai bobot badan yang melebihi bobot badan yang ideal, ternak tersebut akan mengalami penurunan produktivitas dan penya- kit metabolisme lainnya, sebaliknya apabila ternak memiliki bobot badan kurang dari bobot badan ideal akan berdampak pada sistem reproduksinya (Budiawan dkk., 2015). Faktor lingkungan yang memberikan kontribusi terhadap produksi susu yang dihasilkan sapi perah salah satunya adalah pakan (Mukhtar, 2006). Body Condition Score adalah metode pengukuran terhadap keefektifan sistem pemberian pakan pada sapi perah, tujuannya adalah untuk mengetahui pencapaian standar kecukupan cadangan lemak tubuh yang akan mempengaruhi efisiensi reproduksi, sedangkan efisiensi reproduksi sapi perah akan berpengaruh terhadap produksi susu (Sarjowardojo dan Sarwiyono., 2013).

Produksi susu pada Body Condition Score (BCS) yang ideal dalam hasil pene-litiannya adalah kurang lebih 20,16 liter per hari yang menggunakan sistem penilaian BCS 1 sampai dengan 5 (Komala., 2015). Kondisi BCS yang ideal menghasilkan produksi susu yang optimal, namun kenyataan yang ada di peternakan sapi perah terdapat BCS yang kurang dari ideal dan melebihi ideal, sehingga untuk memperoleh tingkat produksi susu yang optimal diperlukan penilain BCS yang sesuai. Kuantitas dan kualitas susu yang rendah pada sapi perah diakibatkan pemberian 
pakan nutrisi yang dibutuhkan ternak untuk memproduksi susu kurang maksimal, dan juga pakan yang berlebih dapat mempengaruhi hasil produksi susu yang dihasilkan (Syarifuddin, 2017). Hal tersebut telah menjadi masalah selama ini. Keadaan ini diperkirakan sebagai akibat dari adanya keterbatasan pengetahuan peternak dalam menentukan BCS yang ideal dalam menghasilkan produksi susu yang optimal.

Berdasarkan latar belakang tersebut maka dilakukan penelitian mengenaiproduksi susu pada sapi perah Friesian Holstein (FH) berdasarkan perbedaan Body Condition Score (BCS). Diharapkan data yang diperoleh dapat menjadi indikator peningkatan produksi pada periode selanjutnya.

\section{Materi dan Metode \\ Waktu dan Tempat penelitian}

Penelitian ini dilaksanakan di peternak kemitraan PT Greenfields Indonesia diwilayah kecamatan Wagir, kabupaten Malang. Penelitian ini dilaksanakan pada bulan April sampai dengan September 2017. Materi yang digunakan adalah pengambilan data catatan reproduksi yang berasal dari sampel sapi Frisian Holstein.

Penelitian menggunakan metode survei. Data yang diambil meliputi data primer dan data sekunder. Data primer yaitu data yang diperoleh dari hasil observasi dan pengamatan serta wawancara secara langsung dengan peternak dengan cara memberikan kuisioner. Sedangkan data sekunder yaitu data yang diperoleh dari catatan reproduksi dengan metode pengambilan sampel dengan sengaja (purposive random sampling) yaitu data ternak sapi perah yang telah produktif atau sudah pernah beranak. Data yang terkumpul dikelompokan berdasarkan BCS kurang dari 5 ,BCS 5 sampai 6, dan BCS lebih dari 6. Pada masing-masing kelompok dilakukan pengambilan 10 sapi secara acak untuk diukur BCS dan produksi susunya.

\section{Produksi Susu Harian}

Produksi susu yang dihasilkan dilakukan melalui pemerahan pada pagi hari dan sore hari.Rata-rata produksi susu per hari berdasarkan catatan peternak, yaitu rata-rata selama masa laktasi

\section{Body Condition Score (BCS)}

Pengukuran BCS dilakukan pada pertengahan laktasi. Evaluasi dengan BCS efektif untuk mengukur sejumlah energi metabolik yang disimpan sebagai lemak subkutan dan otot pada ternak .Body Condition Scoring (BCS) atau skor kondisi tubuhmerupakan metode yang digunakan untuk menilai tingkat kegemukan seekor ternak sapi (Gafar, 2007).Kisaran angka untuk menilai yaitu 1-9, berdasarkan bentuk dan konformasi tubuh).nilai kondisi tubuh yang didasarkan pada estimasi visual timbunan lemak tubuh diba-wah kulit sekitar pangkal ekor,tulang pung-gung, tulang rusuk dan pinggul.Seekor sapi dalam kondisi 'kurus' (BCS 14)berbentuk sudut dan tulang dengan sedikit lemak di tulang punggung, tulang rusuk, kait, dan pin. Tidak ada lemak yang terlihat di sekitar kepala ekor atau Sandung lamur. Sapi dalam kondisi 'ideal' (BCS 5-7) memiliki penam-pilan keseluruhan yang baik. Sapi dengan BCS 6 atau 7 terlihat berdaging dan tulang rusuk tidak lagi terlihat. Dan juga terdapat lemak di sekitar kepala ekor dan di Sandung lamur. Sapi dengan BCS 8 sampai 9 yang terlalu gemuk dan berotot dengan struktur tulang yang tersembunyi dari pandangan atau sentuhan (Ensminger dan Tyler, 2006).

\section{Analisis Data}

Data dalam penelitian ini disusun dalam tabel rataan dan simpangan baku. Untuk me-nguji hubungan antara BCS terhadap pro-duksi susu sapi perah maka dilakukan dengan analisis regresi. BCS berfungsi sebagai variabel bebas sedangakan variabel terikat adalah produksi susu sapi perah Friesian Holstein (FH). Uji untuk mengetahui linearitasnya menggunakan analisis one way Analysis Of Variance (one-way ANOVA)

\section{Hasil dan Pembahasan}

Dari hasil penelitian diketahui rata-rata produksi susu sapi perah Friesian Holstein (FH) antara BCS 3 sampai 4, BCS 5 sampai 6 dan BCS 7 sampai 8 berbeda (Lampiran 4). Body Condition Sore (BCS) dengan produksi susu sapi perah Friesian Holstein $(\mathrm{FH})$ terdapat hubungan quadratik sebesar 20,6\% artinya sebanyak $20.6 \%$ perubahan produksi susu disebabkan oleh Body Condition Score (BCS). Analisis regresi dapat dilihat dalam Lampiran 3. Antara Body Condition Score 
(BCS) dengan produksi susu yang dihasilkan terdapat perbedaan yang nyata $(\mathrm{p}<0.05)$ Ratarata produksi susu disajikan pada Tabel 1 .

Hubungan tersebut ditunjukkan secara matematis hubungan antara Body Condition Score (BCS) dengan produksi susu sapi perah Friesian Holstein $(\mathrm{FH})$ ditunjukkan dengan persamaan :

$$
\begin{aligned}
& Y=6.62+5.54 x-5.78 x^{2} \\
& \text { Keterangan : } \\
& Y=\text { Produksi susu sapi perah } \\
& X=\text { Body condition Score }(B C S
\end{aligned}
$$

Produksi susu pada sapi perah Friesian Holstein (FH) akan terjadi peningkatan pada setiap kenaikan Body Condition Sore (BCS). Produksi susu akan mengalami penurunan setelah Body Condition Score (BCS) berada pada titik tertentu yaitu setelah BCS 6 . Sedangkan pada BCS yang kurang dari ideal akan terjadi produksi susu yang kurang optimal. Kurva hubungan antara BCS dengan produksi susu digambarkan menggunakan curve expert 1.4 dapat dilihat pada gambar 1 . Body Condition Sore (BCS) dengan produksi susu sapi perah Friesian Holstein $(\mathrm{FH})$ terdapat hubungan quadratik sebesar 20,6\% artinya sebanyak $20.6 \%$ perubahan produksi susu disebabkan oleh Body Condition Score (BCS). Produksi susu pada sapi perah Friesian Holstein $(\mathrm{FH})$ akan terjadi peningkatan pada Body Condition Sore (BCS) yang ideal. Produksi susu akan mengalami penurunan setelah BCS berada pada titik tertentu yaitu setelah BCS 6. Sedangkan pada BCS yang kurang dari ideal akan terjadi produksi susu yang kurang optimal.

Berdasarkan tabel menunjukkan bahwa sapi perah dengan BCS kurang dari ideal (34) memproduksi susu kurang optimal, pada sapi perah dengan BCS ideal (5-6) produksi

Tabel 1. Rata-rata produksi susu pada sapi perah dikemitraan PT Greenfield berdasarkan pengelompokkan BCS.

\begin{tabular}{cc}
\hline Perlakuan & Produksi susu \pm SD (liter/hari) \\
\hline BCS $3-4$ & $20,20^{\mathrm{a}} \pm 3,85$ \\
BCS $5-6$ & $20,90^{\mathrm{a}} \pm 7,37$ \\
BCS $7-8$ & $15,60^{\mathrm{b}} \pm 1,34$ \\
\hline
\end{tabular}

Keterrangan : superskrip yang berbeda pada kolom yang menunjukkan perbedaan yang nyata $(\mathrm{p}<0.05)$

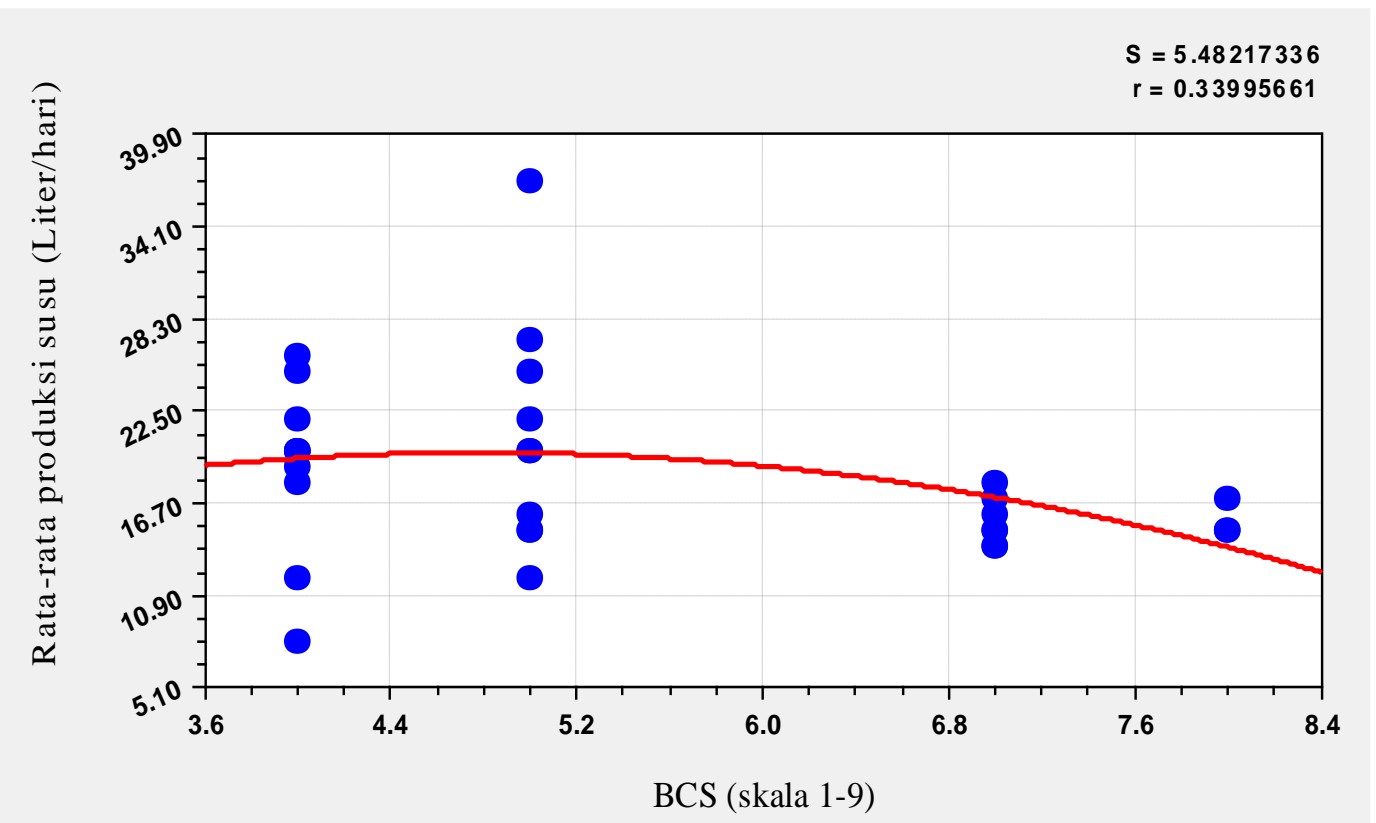

Gambar 1. Grafik Rerata Produksi Susu Sapi Perah Freisian Holstein (FH) berdasarkan perbedaan BCS. 
susu tinggi sedangkan pada sapi perah dengan BCS melebihi ideal (7-8) produksi susu yang dihasilkan sangat rendah. Penelitian sebelumnya, juga menyatakan bahwa Body Condition Score yang ideal menghasilkan produksi susu yang optimal sekitar 18,49 liter per hari dibanding dengan BCS kurang ideal maupun melebihi ideal. Hal ini menunjukkan bahwa kondisi tubuh sapi dewasa yang ideal berkaitan erat dengan produksi susu optimal. Sapi dewasa yang berada pada kondisi tubuh terlalu gemuk atau terlalu kurus akan menurunkan produksi susu (Sukandar dkk., 2009).

Pengaruh Body Condition Score (BCS) terhadap produksi susu yang dihasilkan oleh sapi perah pada penelitian ini menunjukkan nilai Body Condition Score (BCS) yang ideal menghasilkan produksi susu yang optimal. Hal ini disebabkan karena kenyataan diwilayah kemitraan yang menunjukkan BCS ratarata hewan ternaknya berada di kisaran 5 dan 6. Nilai BCS 5 dan 6 menggambarkan sudah baiknya tampilan produktivitas diwilayah tersebut yang artinya nutrisi yang diberikan untuk ternak sapi di daerah tersebut sudah tercukupi.

Tubuh yang kurus menandakan bahwa ternak tersebut kekurangan pakan dan menyebabkan terlambat birahi pada ternak akibat kerja fisiologis dalam tubuh yang kurang baik (Suharto, 2003). Sapi perah yang sedang laktasi akan memerlukan protein yang tinggi, hal ini dikarenakan sapi terus menerus mensekresikan protein dalam bentuk susu. Sehingga perlu pakan dengan kandungan nutrisi yang baik untuk memenuhi kebutuhan pokok ternak itu sendiri dan produksi (Yusuf, 2000).

Energi tubuh yang cukup, digunakan untuk memproduksi Luteinizing Hormone (LH), yang berfungsi untuk merangsang pertumbuhan folikel (mengaktifkan fungsi ovarium) sehingga terjadi estrus post-partus. Dengan kata lain apabila cadangan energi rendah maka estrus post-partus akan lama sehingga mengganggu produktivitas sapi perah (Budiawan, 2015). Sejumlah cadangan lemak tubuh dikumpulkan saat awal laktasi yang menurunkan cadangan lemak tubuh selama satu sampai dua minggu setelah beranak, sampai pengembalian kondisi tubuh terjadi. Perubahan BCS akan mempengaruhi puncak produksi susu dan bentuk kurva produksi susu (Domeq, dkk. 1997).
Kegemukan pada sapi dapat menyebab-kan penimbunan lemak pada saluran repro-duksi terutama ovarium yang dapat menye-babkan gangguan siklus birahi pada sapi pe-rah. Akibat lain yang dapat ditimbulkan dari kegemukan adalah tingkat kebuntingan yang rendah, distokia, abortus, dan retensio secundinae. Hal tersebut dapat mengganggu siklus reproduksi pada sapi perah akibatnya produksi susu yang dihasilkan juga akan berkurang (Bearden et al, 2004). Kegemukan pada sapi perah tidak akan meningkatkan produktivitas tetapi akan meningkatkan penyakit metabolisme dan gangguan reproduksi pada sapi perah. Oleh karena itu, BCS dapat digunakan untuk memonitoring sejumlah cadangan lemak tubuh selanjutnya dapat dipakai untuk menduga keseimbangan energi sapi laktasi. (Mao, dkk. 2004).

Jadi, terdapat hubungan antara Body Conditon Score (BCS) dengan produksi susu sapi perah Freisian Holstein $(\mathrm{FH})$ berdasarkan kelompok Body Conditon Score (BCS). Semakin tinggi nilai BCS maka produksi susu semakin menurun. Pada BCS yang rendah produksi susu yang dihasilkan juga kurang maksimal. Namun pada BCS yang ideal (BCS 5 sampai 6) poduksi susu yang dihasilkan optimal.

\section{Kesimpulan}

Produksi susu tidak meningkat atau mengalami penurunan pada titik tertentu yaitu pada BCS lebih dari 6 (7-8). Pada BCS kurang dari ideal (BCS $3-4$ ) produksi susu yang dihasilkan kurang optimal dibanding dengan BCS yang ideal (5 - 6). Semakin tinggi nilai Body Condition Score (BCS) maka produksi susu yang dihasilkan sapi perah tersebut akan semakin menurun.

\section{DAFTAR PUSTAKA}

Bearden, J.H and S.T. Willard. 2004. Applied Animal., J.W. Fuquay, Reproduction. 6th Ed. Pearson Education, Inc., Upper Saddle River. New Jersey.

Budiawan A., M.N. Ihsan dan Wahjuningsih S. 2015. Hubungan Body Condition Score Terhadap Service Per Conseption dan Calving Interval Sapi Potong Peranakan Ongole di Kecamatan Barat Kabupa-ten Lamongan. Jurnal Tropical animal Husbandry. 16(1): 34-40.

Dirjen Bina Produksi Peternakan. 2008. Statistik Produksi Ternak Direktorat 
Jendral Bina Produksi Peternakan. Departemen Perta-nian.Jakarta.

Domeq, J.J., A.L. Skidmore, J.W. Lloid and J.B. Kaneene. 1997. Relationship between body condition score and milk yield in a large dairy herd of heigh yielding Holstein cows. J. Dairy Sci. 80: $101-112$.

Ensminger, M. E. dan H.D. Tyler. 2006 Dairy Cattle Science. $4^{\text {th }}$ Ed. Danville. The Insterstate Printers and Publisher, Inc. 54-63.

Gafar I.B. 2007. Diktat Ilmu Tilik Sapi Potong. Fakultas Peternakan Universitas Udayana, Denpasar. 102-105.

Irawan, F. 2010. Korelasi Produksi Susu dengan Status Fisiologis Sapi FH (Fries Holland) pada Saat Laktasi di UPTD Ruminansia Besar Dinas Petenakan Kabupaten Kampar [Skripsi] Program Studi Peternakan Fakultas Pertanian dan Peternakan. Uni-versitas Islam Negeri Sultan Syarif Kasim. Pekanbaru.

Komala I., I.Arifiantini, C.Sumantri dan L.I.T.A. Tumbelaka. 2015.Hubungan Produksi Susu Berdasarkan Grade MPPA dengan Performa Reproduksi. 3(1): 33-39.
Mao I.L., K. Sloniewski, P. Madsen, J.Jensen. 2004. Change In Body Condition Score An In Its Genetic Variation During Lactation. J. Liv. Prod Sci. 89: 55-65.

Mukhtar A, 2006. Ilmu Produksi Ternak Perah. Surakarta LPP UNS dan UNS Press. Surakarta. 56-63.

Sarjowardojo P., dan Sarwiyono. 2013. Pengaruh Body Condition Score Sapi Perah Friesian Holstein Bunting Tua terhadap Jumlah dan Kadar Protein Kolostrum. Fakultas Peternakan Universitas Brawijaya.

Setyawan, H., S. I. Santoso dan Mukson. 2005. Analisa Finansial Usaha Peternakan Sapi Perah pada Tingkat Perusahan Peternakan. J. Animal Production 7(1): 40-45.

Suharto, K.2003. Penampilan Potensi Reproduksi Sapi Perah Freisian Holstein Akibat Pemberian Kualitas Ransum Berbeda dan Infusi Larutan Iodium Povidon 1\% Intra Uterin. Tesis Program Studi Magistter Ilmu Ternak Universitas Diponegoro. Semarang. 